\title{
SFRP1 reduction results in an increased sensitivity to TGF- $\beta$ signaling
}

Kelly J Gauger ${ }^{1,3^{*}}$, Kerry L Chenausky ${ }^{2}$, Molly E Murray ${ }^{3}$, Sallie S Schneider ${ }^{1,4^{*}}$

\begin{abstract}
Background: Transforming growth factor (TGF)- $\beta$ plays a dual role during mammary gland development and tumorigenesis and has been shown to stimulate epithelial-mesenchymal transition (EMT) as well as cellular migration. The Wnt/ $\beta$-catenin pathway is also implicated in EMT and inappropriate activation of the Wnt/ $\beta$-catenin signaling pathway leads to the development of several human cancers, including breast cancer. Secreted frizzledrelated protein 1 (SFRP1) antagonizes this pathway and loss of SFRP1 expression is frequently observed in breast tumors and breast cancer cell lines. We previously showed that when SFRP1 is knocked down in immortalized non-malignant mammary epithelial cells, the cells (TERT-siSFRP1) acquire characteristics associated with breast tumor initiating cells. The phenotypic and genotypic changes that occur in response to SFRP1 loss are consistent with EMT, including a substantial increase in the expression of ZEB2. Considering that ZEB2 has been shown to interact with mediators of TGF- $\beta$ signaling, we sought to determine whether TGF- $\beta$ signaling is altered in TERTsiSFRP1 cells.
\end{abstract}

Methods: Luciferase reporter assays and real-time PCR analysis were employed to measure TGF- $\beta$ transcriptional targets. Western blot analysis was used to evaluate TGF- $\beta$-mediated ERK1/2 phosphorylation. Migration chamber assays were utilized to quantify cellular migration. TERT-siSFRP1 cells were transfected with Stealth RNAiTM siRNA in order to knock-down the expression of ZEB2.

Results: TERT-siSFRP1 cells exhibit a significant increase in both TGF- $\beta$-mediated luciferase activity as well as TGF- $\beta$ transcriptional targets, including Integrin $\beta_{3}$ and PAI-1. Phosphorylation of ERK1/2 is increased in TERT-siSFRP1 cells in response to enhanced TGF- $\beta$ signaling. Furthermore, when the TGF- $\beta$ pathway is blocked with a TGF- $\beta$ R antagonist (LY364947), cellular migration is significantly hindered. Finally, we found that when ZEB2 is knockeddown, there is a significant reduction in the expression of exogeneous and endogenous TGF- $\beta$ transcriptional targets and cellular migration is impeded.

Conclusions: We demonstrate that down-regulation of SFRP1 renders mammary epithelial cells more sensitive to TGF- $\beta$ signaling which can be partially ameliorated by blocking the expression of ZEB2.

\section{Background}

Breast cancer is the most frequently occurring cancer in women and between $12 \%$ and $13 \%$ of women will develop invasive breast cancer over the course of their lifetime. Cancer results from cellular mutations that enhance proliferation, decrease tumor suppressive signals, and decrease programmed cell death; and from cellular alterations that enhance angiogenesis and metastasis [1]. Notably, metastasis is the most deadly

\footnotetext{
* Correspondence: kelly.gauger@bhs.org; sallie.schneider@baystatehealth.org 'Pioneer Valley Life Sciences Institute, Baystate Medical Center, Springfield, MA 01199, USA

Full list of author information is available at the end of the article
}

aspect of breast cancer and takes place when invasive epithelial cells in a primary tumor leave their site of origin, digest and break through the extracellular matrix, migrate into blood vessels, and invade secondary sites. Epithelial-mesenchymal transition (EMT) is a process whereby epithelial cells lose polarity as well as cell-cell contacts and undergo a dramatic remodeling of the cytoskeleton resulting in a highly motile mesenchymal morphology. Inappropriate reactivation of EMT is implicated in the conversion of early stage breast tumors into invasive malignancies. Unfortunately, the molecular mechanisms by which EMT mediates the initiation of breast cancer metastasis remain poorly understood.

\section{Biomed Central}


Transforming growth factor (TGF) $\beta$ is a multifunctional cytokine that regulates a variety of physiological processes and also plays a dual role during mammary gland development and tumorigenesis. TGF- $\beta$ signaling is manifested by way of TGF- $\beta$ receptor activation and the canonical pathway involves the subsequent phosphorylation of receptor-associated Smad2 and Smad3 proteins which form complexes with Smad4. These activated Smad complexes accumulate in the nucleus where, along with co-activators and cell-specific DNA-binding factors, they regulate gene expression. In early stage breast malignancies, TGF- $\beta$ functions as a powerful tumor suppressor by blocking cell cycle progression, but TGF- $\beta$ signaling can become deregulated during mammary tumorigenesis $[2,3]$. The neoplastic tumor cell environment ultimately transforms TGF- $\beta$ into an oncogenic cytokine which actively contributes to the acquisition and development of metastatic phenotypes in part through its ability to stimulate EMT and cellular migration [4-7].

Similar to the TGF- $\beta$ pathway, the Wnt/ $\beta$-catenin pathway is also implicated in EMT and epithelial plasticity during development and cancer. Wnt ligands activate the $\mathrm{Wnt} / \beta$-catenin signaling pathway by binding to receptors comprised of Frizzled proteins in conjunction with one of the LDL receptor-related proteins LRP5 or LRP6. Receptor activation results in the ability of a cytoplasmic protein, Dsh, to dissociate and inactivate a multiprotein complex that includes APC, Axin, and GSK3 $\beta$. As a result, $\beta$-catenin is free to accumulate in the nucleus where it forms a complex with the TCF/ LEF1 family of HMG box transcription factors and stimulates the expression of specific target genes. Inappropriate activation of the $\mathrm{Wnt} / \beta$-catenin pathway, which results from mutations in several downstream genes, contributes to the genesis of a wide range of human cancers [8]. However, such mutations are rarely observed in breast cancer despite the finding that $\beta$-catenin is stabilized and Wnt signaling is activated in a majority of human breast tumors [9]. In addition, aberrantly activated Wnt signaling leads to inappropriate mammary gland development and mammary tumorigenesis in mice [10].

Secreted frizzled-related protein-1 (SFRP1) is a powerful Wnt signaling antagonist that contains a cysteinerich domain that is homologous to the Wnt-binding domain of frizzled receptor proteins [11]. Since SFRP1 lacks a transmembrane domain, it is free to remain in the extracellular compartment and block Wnt/ $\beta$-catenin signaling by binding to Wnt ligands and preventing ligand-receptor interactions [12]. Loss of SFRP1 expression is found in a multitude of cancers including breast cancer [13-15].

When SFRP1 is knocked down in immortalized nonmalignant mammary epithelial cells, the cells (TERT-
siSFRP1) exhibit a malignant phenotype which resembles the characteristics observed in metastatic breast cancer cells [16]. Interestingly, the phenotypic and genotypic changes that occur in response to SFRP1 loss are consistent with EMT. Among the EMT associated genes analyzed, loss of SFRP1 resulted in a drastic increase in the expression of ZEB2. Originally, ZEB2 was named Smad interacting protein 1 (SIP1) due to it's ability to act in a ligand-dependent fashion with receptor-activated Smads and mediate TGF- $\beta$ signaling [17]. More recently, studies have revealed that ZEB2 is characterized by $\mathrm{N}$-terminal and $\mathrm{C}$-terminal zinc-finger clusters that can regulate the transcription of EMT markers by binding to 5'-CACCT sequences located in various gene promoters [18]. The work described here was initiated to investigate whether the TGF- $\beta$ signaling pathway is affected by SFRP1 loss. We demonstrate that down-regulation of SFRP1 renders mammary epithelial cells more sensitive to TGF- $\beta$ signaling which can be partially ameliorated by blocking the expression of ZEB2.

\section{Methods}

\section{Cell Culture and Treatments}

The 76N TERT cell line (obtained from Dr. Vimla Band) were stably transfected with either pSUPER.retro (TERT-pSUPER) or siSFRP1-PSUPER.retro (TERTsiSFRP1) as previously described [16]. Cells were routinely cultivated at $37^{\circ} \mathrm{C}$ in $5 \% \mathrm{CO}_{2}$ and maintained in DMEM/F12 (GIBCO, Grand Island, NY) and the following components from GIBCO: 1\% FBS, 1X AntibioticAntimycotic (100X), and $20 \mu \mathrm{g} / \mathrm{mL}$ Gentamycin. The following components from Sigma (St Louis, MO) were also used: $50 \mu \mathrm{M} \mathrm{L}(+)$-Ascorbic acid sodium salt, 1ng/ $\mathrm{ml}$ Cholera Toxin Vibrio, $12.5 \mathrm{ng} / \mathrm{ml}$ Epidermal Growth Factor murine submaxillary, $2 \mathrm{nM} \beta$-Estradiol, $0.1 \mathrm{mM}$ Ethanolamine, $1 \mu \mathrm{g} / \mathrm{ml}$ Hydrocortisone-Water Soluble, $1 \mu \mathrm{g} / \mathrm{ml}$ human Insulin solution, $0.1 \mathrm{mM}$ O-Phosphorylethanolamine, $35 \mu \mathrm{g} / \mathrm{ml}$ bovine pituitary extract, $15 \mathrm{nM}$ Sodium selenite, $10 \mu \mathrm{g} / \mathrm{ml}$ human apo-Transferrin, and 10 nM 3,3',5-Triiodo-L-thyronine sodium salt. Cells were plated in 6-well plates (for RNA isolation) and $10 \mathrm{~cm}$ dishes (for protein isolation) and allowed to attach overnight. The following day, media was changed to contain vehicle $(0.1 \% \mathrm{BSA} / 4 \mathrm{mM} \mathrm{HCl}), 2.5 \mathrm{ng} / \mathrm{ml}$ TGF- $\beta 1$ (Sigma), vehicle (DMSO), $5 \mu \mathrm{M}$ UO126, and/or $10 \mu \mathrm{M}$ LY364947 (sigma). For ZEB2 knock down studies, 62.5 nM ZEB2 Stealth RNAi ${ }^{\text {TM }}$ siRNA (Invitrogen) was transfected into cells using Lipofectamine ${ }^{\mathrm{TM}}$ 2000 (Invitrogen).

\section{Luciferase Assay}

A total of $1 \times 10^{5}$ cells/well were plated in 24 well plates and were transfected the following day with $0.8 \mu \mathrm{g}$ CAGA-Luc and $0.08 \mu \mathrm{g}$ pRL-CMV using lipofectamine 
TM 2000 (Invitrogen). After a 6 hour incubation, the media was removed and replaced with treatment media [either vehicle $(0.1 \% \mathrm{BSA} / 4 \mathrm{mM} \mathrm{HCl})$ or $2.5 \mathrm{ng} / \mathrm{ml}$ TGF- $\beta 1]$. Twenty-four hours after treatment, cells were washed with $1 \mathrm{X}$ PBS and lysed using passive lysis buffer (Promega). Luciferase activity was detected using the Dual-Luciferase $^{\circledR}$ reporter assay system (Promega) according to the manufacture's instructions and the light output was measured with a luminometer (TD 20/20 Luminometer, Turner Biosystems, Sunnyvale, CA).

\section{RNA Isolation and Real-Time PCR}

Total RNA was extracted from treated cells using an acid-phenol extraction procedure [19], according to the manufacturer's instructions (Trizol, Invitrogen, Carlsbad, CA). Relative levels of mRNA were determined by quantitative real-time PCR using the $\mathrm{Mx} 3005 \mathrm{P}^{\mathrm{TM}}$ real time PCR system (Stratagene, La Jolla, CA) and all values were normalized to the amplification of $\beta$-Actin. The PCR primer sequences used are as follows: TGF$\beta 2$ forward: 5' - CCAAAGGGTACAATGCCAAC -3', TGF- $\beta 2$ reverse: 5 ' - CAGATGCTTCTGGATTTATGGT ATT-3'; Six1 forward: 5'- ACCGGAGGCAAAGAGACC -3', Six1 reverse: 5'- GGAGAGAGTTGATTCTGCTT GTT -3'; $\beta_{3}$ Integrin forward: 5'- GGGCA GTGTCATG TTGGTAG -3', $\beta_{3}$ Integrin reverse: 5'- CAGCCCCAAA GAGGGATAAT -3'; PAI-1 forward: 5'- TCCAGCA GCTGAATTCCTG -3', PAI-1 reverse: 5'- GCTGGA GACATCTGCATCCT -3', ZEB2 forward: 5' - AAGC CAGGGACAGATCAGC-3', ZEB2 reverse: 5' - CCA CACTCTGTGCATTTGAACT-3', $\beta$-Actin forward: 5'CCAACCGCGAGAAGATGA-3'; $\beta$-Actin reverse: 5'CCAGAGGCGTACAGGGATAG-3'. The assays were performed using the 1 -Step Brilliant ${ }^{\circledR}$ SYBRII ${ }^{\circledR}$ Green QRT-PCR Master Mix Kit (Stratagene) containing $200 \mathrm{nM}$ forward primer, $200 \mathrm{nM}$ reverse primer, and 100 ng total RNA. The conditions for cDNA synthesis and target mRNA amplification were performed as follows: 1 cycle of $50^{\circ} \mathrm{C}$ for $30 \mathrm{~min} ; 1$ cycle of $95^{\circ} \mathrm{C}$ for $10 \mathrm{~min}$; and 35 cycles each of $95^{\circ} \mathrm{C}$ for $30 \mathrm{~s}, 55^{\circ} \mathrm{C}$ for $1 \mathrm{~min}$, and $72^{\circ} \mathrm{C}$ for $30 \mathrm{~s}$.

\section{Western Blot Analysis}

Treated cells were washed twice with cold PBS and $100 \mu \mathrm{L}$ of cold lysis buffer [50 mM Tris- $\mathrm{HCl}, 150 \mathrm{mM}$ $\mathrm{NaCl}, 100 \mathrm{mM} \mathrm{NaF}, 10 \mathrm{mM} \mathrm{MgCl}_{2}, 0.5 \% \mathrm{NP} 40$, protease inhibitor cocktail, and phosphatase inhibitor I and II (Sigma)] was added directly to the plate. The cells were incubated for 30 minutes at $4{ }^{\circ} \mathrm{C}$ on a shaker and then harvested using a rubber policeman. The lysates were passed 4 times through a 26 gauge syringe, kept on ice for 30 minutes, and then centrifuged for 20 minutes at $12,000 \mathrm{rpms}$ at $4^{\circ} \mathrm{C}$. The supernatant was transferred to a new tube and the protein was quantified utilizing the BCA ${ }^{\mathrm{TM}}$ Protein Assay Kit (Pierce, Rockford, IL). A total of $50 \mu \mathrm{g}$ of protein was run on a $10 \%$ SDS-Page gel and transferred to a PVDF membrane. The membrane was blocked for 45 minutes with $5 \%$ milk in tris-buffered saline containing $0.05 \%$ Tween-20 (TBS-T). The primary antibodies used in this study were [Rabbit phospho-ERK1/ 2 (Thr202/Tyr204) (1:1000), \#4377, Cell Signaling Technologies, Danvers, MA; Rabbit ERK1/2 (1:1000), sc-94, Santa Cruz Biotechnology, Santa Cruz, CA; Rabbit $\beta$-actin (1:2000), ab8227, Abcam, Cambridge, MA] incubated overnight at $4^{\circ} \mathrm{C}$. The secondary antibody [goat anti-rabbit IgG-HRP (Santa Cruz Biotechnology) was applied (1:5000) and incubated for 45 minutes at room temperature. The blot was washed and developed using a Western Blot Luminol Reagent (Santa Cruz Biotechnology).

\section{Transwell Migration Assays}

Treated cells were trypsinized, centrifuged at 1,000 $\times \mathrm{g}$ for $3 \mathrm{~min}$, and brought to a concentration of $1 \times$ $10^{6} \mathrm{cells} / \mathrm{ml}$ in serum-free media. $5 \times 10^{5} \mathrm{cells} /$ well were seeded in serum free media (containing DMSO or $10 \mu \mathrm{M}$ LY364947) either in BD BioCoat control chambers (BD Biosciences) above media containing 10\% FBS. Following a 22-hour incubation, chambers were removed and cells were fixed for $10 \mathrm{~min}$ in $10 \%$ formalin, stained for 10 min with $10 \%$ Crystal Violet, and rinsed $3 \mathrm{X}$ with $\mathrm{dH}_{2} \mathrm{O}$. Non-migrating were removed from the upper surface of the membrane by scrubbing the insert with a cotton tipped swab moistened with $1 \mathrm{X}$ PBS. The insert was then removed from the chamber with a scalpel, and mounted on a microscope slide in Cytoseal $^{\mathrm{TM}}$ XYL mounting medium (Richard-Allan Scientific). Images were captured with an Olympic BX41 light microscope using SPOTSOFTWARE (Diagnostic Instruments, Inc, Sterling Heights, MI).

\section{Results}

\section{SFRP1 loss stimulates the TGF $\beta$ signaling pathway}

Our initial screen of genes affected by SFRP1 loss in HMECs identified several upregulated genes within the TGF- $\beta$ pathway, which suggested that there may be an alteration in this signaling pathway in TERTsiSFRP1 cells (Additional File 1). The increased expression of upstream regulators of TGF- $\beta$ signaling included the TGF- $\beta 2$ ligand as well as Six1, a homeodomain protein which promotes TGF- $\beta$-mediated EMT [20]. Also, mRNA levels of ZEB2 were elevated in TERTsiSFRP1 cells and ZEB2 has been shown to interact with downstream mediators of TGF- $\beta$ signaling (Smads) and has been suggested to be involved in TGF- $\beta$-induced EMT [21]. Finally, Integrin $\beta_{3}$ and plasminogin activator inhibitor type-1 (PAI-1), which are transcriptional targets of the TGF- $\beta$ signaling pathway $[22,23]$, were significantly up-regulated in response to loss of SFRP1. Taken 
together, we directly tested the hypothesis that TGF- $\beta$ signaling is augmented in TERT-siSFRP1 cells. First, TERT-pSUPER and TERT-siSFRP1 cells were transfected with a TGF- $\beta$ reporter construct, CAGA-Luc, and grown overnight in the presence or absence of TGF- $\beta 1$. Twenty-four hours after transfection, luciferase activity was measured and we found that TERTsiSFRP1 cells exhibited a significant increase in relative luciferase activity when grown in the presence of the TGF- $\beta 1$ ligand (Figure 1 ). Next, we sought to determine whether endogenous TGF- $\beta$ responsive gene expression is altered in response to SFRP1 loss. Since both Integrin $\beta_{3}$ and PAI-1 are transcriptionally upregulated in response to TGF- $\beta 1$ treatment, we decided to measure the mRNA expression of these genes in TERT-siSFRP1 cells and the effect of TGF- $\beta 1$ treatment on these genes. The expression of both Integrin $\beta_{3}$ and PAI-1 was significantly up-regulated in response to SFRP1 loss and treatment with TGF$\beta 1$ further increases the mRNA expression levels of Integrin $\beta_{3}$ in TERT-siSFRP1 cells (Figure 2A, upper panels). To verify that the expression of these TGF- $\beta$ targets was due to aberrant TGF- $\beta$ signaling in response to SFRP1 down-regulation, cells were treated with a TGF- $\beta$ receptor (TGF- $\beta$ R1) specific inhibitor (LY364957) and gene expression was again analyzed by way of real-time PCR. Our results clearly demonstrate that the expression of both Integrin $\beta_{3}$ and PAI- 1 is significantly inhibited in response to LY364947 treatment in TERT-siSFRP1 cells (Figure 2B, lower panels).

\section{Loss of SFRP1 increases the phosphorylation of ERK1/2 through TGF- $\beta$ signaling}

TGF- $\beta$ signaling has been shown to increase the phosphorylation of ERK1/2 so we first sought to establish

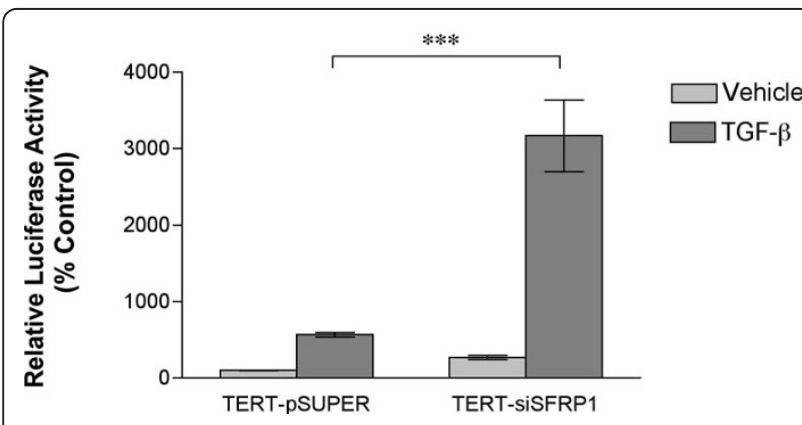

Figure 1 Loss of SFRP1 enhances TGF- $\beta$ signaling activity. TERTPSUPER and TERT-siSFRP1 cells were transfected with the CAGA-Luc and CMV-Renilla reporter vectors and relative luciferase activity was measured after an overnight incubation in the presence or absence of the $2.5 \mathrm{ng} / \mathrm{ml}$ TGF- $\beta$ 1. Bars represent mean \pm SEM of relative luciferase activity (firefly luciferase activity/renilla luciferase activity) normalized to the relative luciferase activity in TERT-pSUPER cells treated with vehicle. ${ }^{* *} p<0.001$ [significantly different from corresponding TERT-pSUPER cell line using students's t-test]. whether of ERK1/2 is phosphorylated in response to loss of SFRP1. Western blot analysis revealed that TERT-siSFRP1 cells express higher levels of phosphorylated ERK1/2 and treatment with an ERK1/2 specific inhibitor (U0126) confirmed that ERK1/2 activation was through a Mek-dependent phosphorylation (Figure 3A, upper left panel). We next wanted to determine whether treatment with TGF- $\beta 1$ could induce the phosphorylation of ERK1/2 in immortalized HMECs and whether the phosphorylation of ERK1/2 we observe in the TERT-siSFRP1 cells could be blocked by antagonizing the TGF- $\beta$ R with LY364947. Our results illustrate that in our control cell line (TERT-pSUPER), ERK1/2 phosphorylation was observed in response to TGF$\beta 1$ treatment and blocking the TGF- $\beta \mathrm{R}$ abrogated this activation. As expected, ERK1/2 was constitutively phosphorylated in TERT-siSFRP1 cells even in the absence of TGF- $\beta 1$ treatment (Figure 3B, upper right panel). Interestingly, treatment with LY364947 reduced the levels of ERK1/2 phosphorylation, independent of TGF$\beta 1$ stimulation, which supports the notion that these cells are not only more sensitive to TGF- $\beta$, but that TGF- $\beta$ signaling pathway is also aberrantly activated in TERT-siSFRP1 cells.

TGF- $\beta$ has been demonstrated to play an important role in activating cellular migration in part by way of ERK1/2 signaling in breast cancer cells [24]. Considering that ERK1/2 is phosphorylated and TGF- $\beta$ signaling is misregulated in TERT-siFRP1 cells, we tested the hypothesis that the increase in cellular migration observed in response to SFRP1 loss may be partially due to these two aforementioned observations. First, a simple scratch wound assay revealed that TERT-siSFRP1 cells treated with LY364947 were much less motile then cells treated with vehicle (data not shown). These results were confirmed using migration chamber assays. Control cells (TERT-pSUPER) and TERT-siSFRP1 cells were plated in BD BioCoat ${ }^{\mathrm{TM}}$ control chambers and the cells capable of migrating through the $8 \mu \mathrm{m}$ pore towards a chemoattractant were stained with $10 \%$ crystal violet and quantified. We clearly show that by blocking the TGF- $\beta$ pathway with LY364947, we could significantly hinder the migratory action of TERT-siSFRP1 cells (Figure 3C, lower panel)

TGF- $\beta$ signaling is mediated by ZEB2 in TERT-siSFRP1 cells ZEB2 was originally characterized as a Smad interacting protein (SIP) and regulator of TGF- $\beta$ signaling [17]. We therefore hypothesized that the significant up-regulation of ZEB2 that occurs in response to SFRP1 loss may partially explain the enhanced constitutive activation of TGF- $\beta$ signaling in TERT-siSFRP1 cells. To test this hypothesis, we knocked-down ZEB2 using siRNAs and real-time PCR analysis verified that there was a significant 


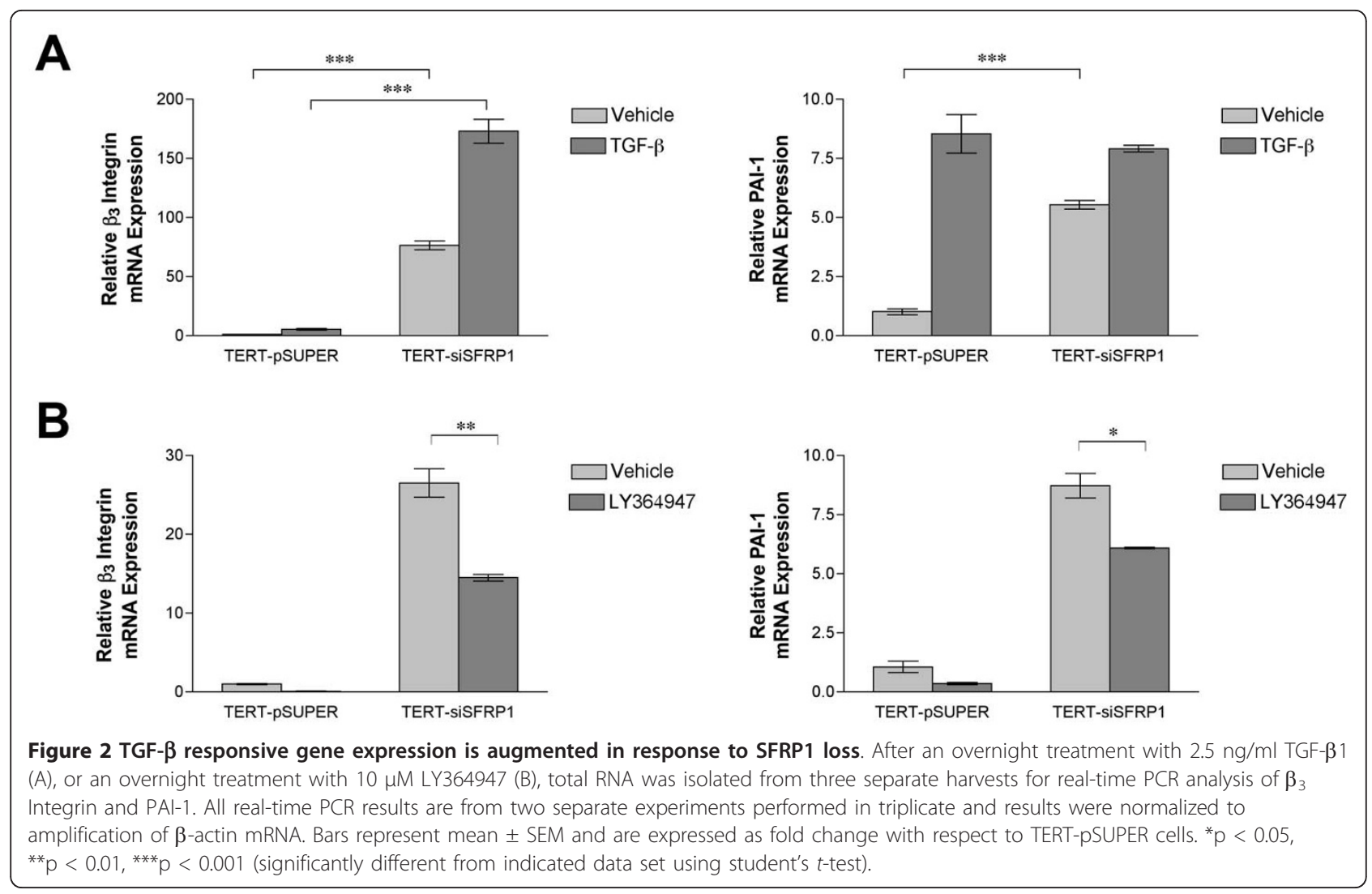

decrease in the mRNA expression of ZEB2 (Figure 4A, upper left panel). Next, TERT-siSFRP1 cells were transfected with control or ZEB2 specific siRNAs, as well as the CAGA-Luc reporter vector, and grown overnight in the presence or absence of TGF- $\beta 1$. Twenty-four hours after transfection, the luciferase activity was measured. We found that when ZEB2 levels were repressed in TERTsiSFRP1 cells, relative CAGA-luciferase activity was significantly hampered in response to TGF- $\beta 1$ treatment (Figure 4B, upper right panel). In addition, real-time PCR analysis confirmed that the mRNA expression of TGF- $\beta$ responsive genes, including Integrin $\beta_{3}$ and PAI-1, was significantly down-regulated when ZEB2 is knocked down in TERT-siSFRP1 cells (Figure 4C, lower panel). Finally, we wished to determine whether similar to TGF- $\beta$ R inhibition, ZEB2 blockade could inhibit cellular migration. Following transfection with control or ZEB2 specific siRNAs, a migration assay using $\mathrm{BD}$ BioCoat ${ }^{\mathrm{TM}}$ control chambers was carried out and revealed that ZEB2 knockdown reduced the number of TERT-siSFRP1 cells that were capable of migrating through the $8 \mu \mathrm{m}$ pore towards the chemoattractant (Figure 5A, upper panel). The number of cells was quantified and we confirmed that in response to ZEB2 down-regulation, cellular migration was significantly reduced (Figure 5B, lower panel).

\section{Discussion}

The present study indicates that loss of SFRP1 expression allows an immortalized non-malignant cell line $(76 \mathrm{~N}$ TERT) to acquire sensitivity to TGF- $\beta$ signaling due to inappropriate activation of ZEB2. These cells with SFRP1 knocked down (TERT-siSFRP1) display a significant increase in both exogeneous and endogenous TGF- $\beta$ transcriptional targets, which is further enhanced by the presence of TGF $\beta$. Moreover, ERK1/2 phosphorylation is increased in TERT-siSFRP1 cells by way of enhanced TGF- $\beta$ signaling. The TGF- $\beta$-mediated activation partially explains the migratory phenotype of TERT-siSFRP1 cells considering that when the TGF- $\beta$ pathway is blocked with LY364947, cellular migration is significantly hindered. Based on our ZEB2 knockdown experiments, the significant upregulation of ZEB2 that occurs in response to SFRP1 loss partially explains the mechanism by which TGF- $\beta$ signaling is mis-regulated in TERT-siSFRP1 cells. We clearly show that exogeneous and endogenous TGF- $\beta$ transcriptional targets, which are upregulated in TERT-siSFRP1 cells, are repressed when the levels of ZEB2 mRNA are decreased. Finally, we found that similar to TGF- $\beta$ R inhibition, ZEB2 blockade inhibits cellular migration.

Previously, we demonstrated that the Wnt $/ \beta$-catenin signaling pathway is significantly up-regulated in 


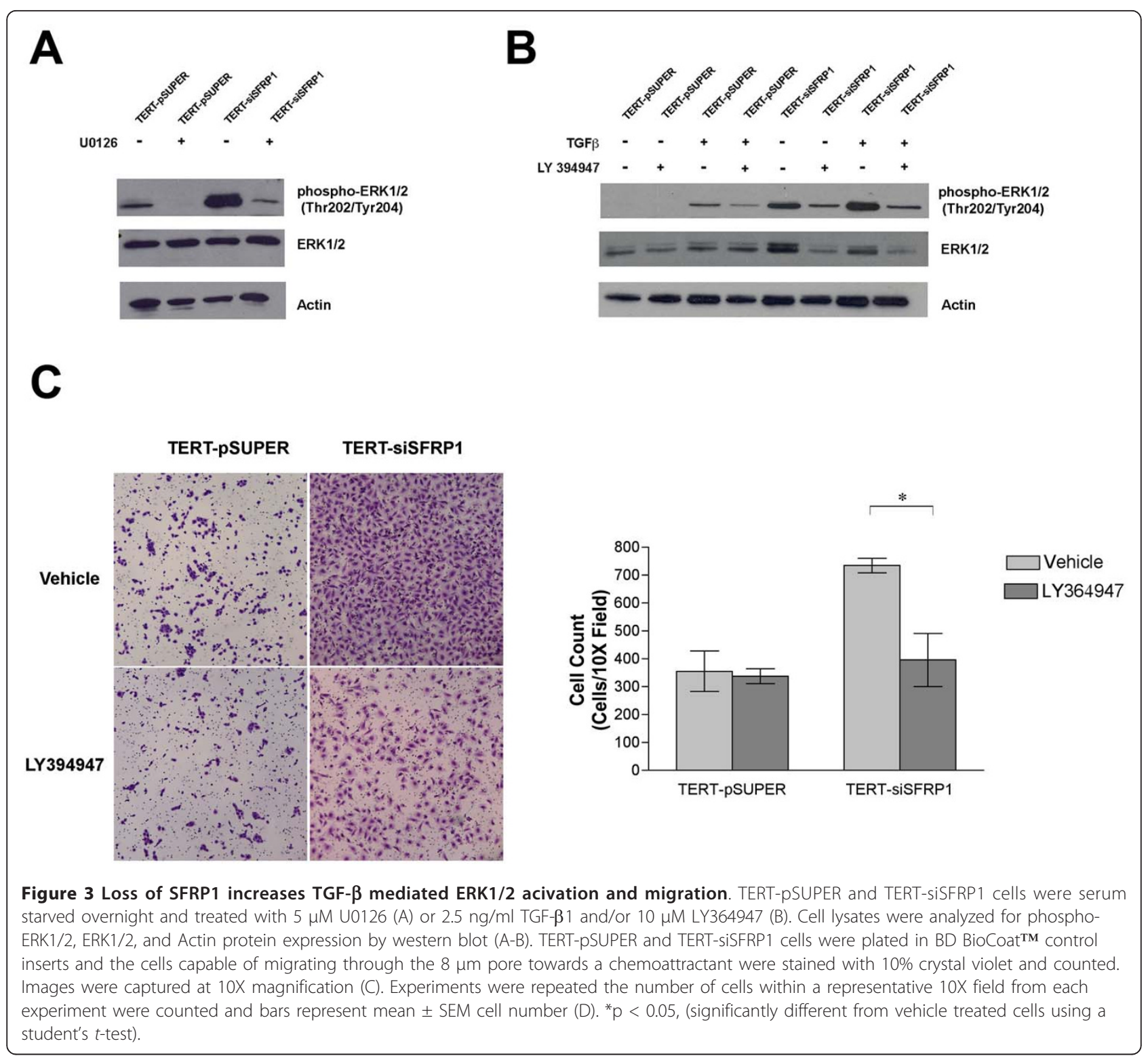

response to SFRP1 loss [16]. Several different developmental processes and patterning events require inputs from both Wnt and TGF- $\beta$ family members $[25,26]$. Work by Labbe et. al [27] identified a cohort of genes that are dually affected by both Wnt and TGF- $\beta$ ligands. Interestingly, several of these genes are elevated in tumors derived from the MMTV-Wnt-1 mouse model and when TGF- $\beta$ signaling is blocked by overexpression of the dominant negative type II TGF- $\beta$ receptor, the expression these genes is not only lost, but there is an increase in tumor-free survival. These data indicate that crosstalk between the Wnt signaling pathway and TGF$\beta$ cooperate to promote tumor development. Mechanistically, this phenomenon may be partially explained by the finding that Wnt mediated $\beta$-catenin translocation results in association with the Lef1 transcription factor, which has been shown to interact with Smad4 and upregulate TGF- $\beta$ targets [28]. Thus, the Wnt signaling status of TERT-siSFRP1 likely predicts the TGF- $\beta$ activity we report here.

The data presented in this article clearly illustrate that TERT-siSFRP1 cells are significantly more sensitive to TGF- $\beta$ signaling. Not only does TGF- $\beta$ play a dual role in tumor progression, but it also known to play an important role in human embryonic stem cells [29]. Considering that TERT-siSFRP1 cells exhibit cancer initiating-cell-like characteristics and display a CD $44^{\text {high }}$ / CD24 ${ }^{\text {low }}$ cell surface marker expression pattern $[16,30]$, our current results are fully consistent with previously published research by Shipitsin et. al showing that 


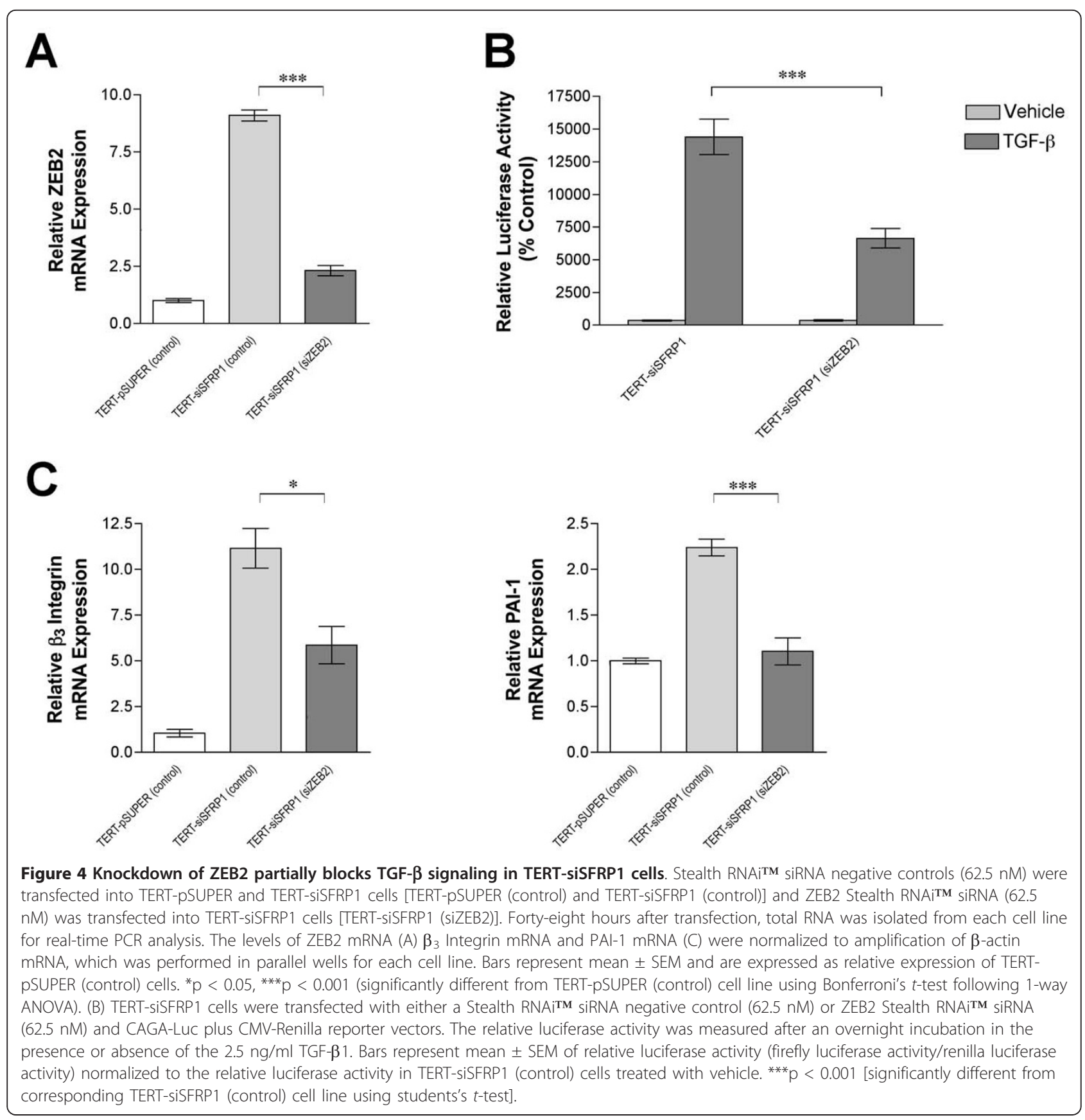

CD $44^{\text {high }} / \mathrm{CD} 24^{\text {low }}$ cells are more responsive to TGF- $\beta$ and can be specifically targeted by TGF- $\beta$ R inhibition [31]. These data support the notion that the Wnt/ $\beta$ catenin and TGF $\beta$ signaling pathways are feeding into each other and facilitating the development of aggressive tumor characteristics.

Downstream transcriptional targets of TGF- $\beta$, including Integrin $\beta_{3}$ and PAI-1 are also significantly more sensitive to TGF- $\beta$ when the expression of SFRP1 is knocked down. The finding that Integrin $\beta_{3}$ is upregulated in TERT-siSFRP1 partially explains the migratory and invasive characteristics exhibited by these cells. When breast cancer cells express Integrin $\beta_{3}$, their invasiveness is enhanced in vivo [32]. Also, it has previously been shown that the induction of Integrin $\beta_{3}$ expression during mammary tumorigenesis correlates with the development of metastases and that when Integrin $\beta_{3}$ is antagonized, breast cancer cell invasion abolished [33]. Consistent with what we present in this current report, Galliher et. al demonstrate that the expression of Integrin $\beta_{3}$ alters the response of mammary epithelial cells to TGF- $\beta$-mediated EMT [33]. Interestingly, small 


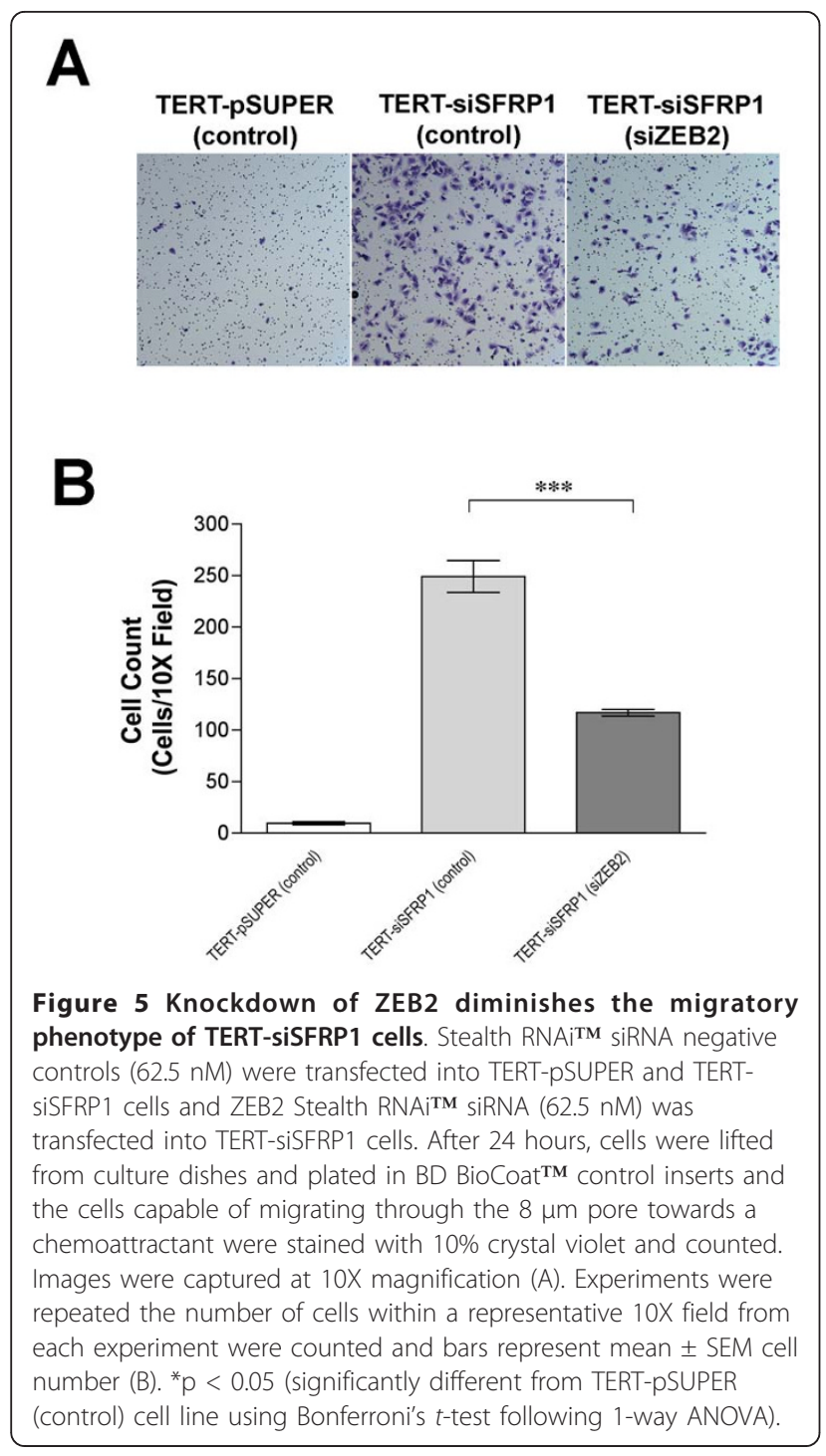

molecule inhibitors of Integrin $\beta_{3}$ are currently being developed as anti-cancer therapeutics [34]. Likewise, PAI-1 is also a proposed anti-cancer target [35]. Several components of the plasminogen activation system, including PA1-1, are implicated in tissue remodeling associated with both physiological and pathologic processes such as wound healing, mammary gland involution, angiogenesis, and cancer invasion [36]. Specifically, PAI-1 promotes tumor growth, angiogenesis, and metastasis [37-40]. Our findings show that by reducing ZEB2 levels, we can subsequently reduce the expression of both Integrin $\beta_{3}$ and PAI-1. Taken together, these data suggest that ZEB2 is a central transcriptional regulator, which controls gene expression necessary for the progression of metastatic cancer. Elloul et. al. [41] analyzed the expression of ZEB2 as well as other transcriptional repressors of $\mathrm{E}$-cadherin in ovarian and breast carcinoma effusions and revealed that elevated mRNA levels of ZEB2 are a predictor of poor survival [41]. Thus, ZEB2 may be an important anti-cancer therapeutic target.

In order to establish whether TGF- $\beta$ signaling elicits a direct physiological consequence when SFRP1 is downregulated, we measured activated ERK1/2 levels and the migratory action of in TERT-siSFRP1 cells in response to TGF- $\beta$ R inhibition. As hypothesized, when cells were treated with LY364947, ERK1/2 phosphorylation and cellular migration were drastically reduced. Our results are consistent with previous research which has shown that TGF- $\beta$ signaling mediates the cellular migration of breast cancer cells by several pathways including ERK1/ 2 activation [42]. Interestingly, the mechanism by which TGF- $\beta$ phosphorylates ERK1/2 is independent of Smad4, as evidenced by TGF- $\beta$ induced phosphorylation of ERK1/2 in the Smad4 deficient MDA-MB-468 cell line [24]. Our data would agree with this observation. Knock down of ZEB2 did not affect the levels of phosphorylated ERK1/2 (data not shown), however inhibition of the TGF- $\beta$ R did affect the ERK1/2 phosphorylation observed in TERT-siSFRP1 suggesting that loss of ZEB2 affects the canonical TGF $\beta$-Smad pathway, but not other TGF- $\beta$ initiated pathways. Alternatively, the phosphorylation of ERK1/2 in TERT-siSFRP1 cells may require input from multiple signaling pathways. Since ZEB2 is likely augmenting TGF- $\beta$ signaling by way of its Smad interacting domain, the mechanisms by which the TGF- $\beta$ pathway affects cellular migration in TERTsiSFRP1 cells seems to involve both Smad-independent (ERK1/2) and Smad-dependent (ZEB2) actions.

It has been suggested that overexpression of ZEB2 plays a putative role in oncogenic transformation since it was identified in a large-scale screen for cancer related genes [43]. Data illustrating that high levels of ZEB2 are expressed in migratory breast cancer cell lines (MDA-MB-231 and MDA-MB-435S1) but not in breast cancer cells with a more epithelial/less migratory phenotype (MCF7/AZ) [44] supports our finding that ZEB2 repression hampers the cellular migration. It is thought that the mechanism by which ZEB2 induces EMT is by its ability to repress the epithelial cell junction protein E-cadherin and induce the mesenchymal marker, vimentin, in breast cancer cell lines [45]. However, the decrease in cellular migration that occurs in response to ZEB2 down-regulation in TERT-siSFRP1 is independent of E-cadherin and vimentin, as the mRNA levels of these genes are only marginally affected by ZEB2 knockdown (data not shown). The down-regulation of E-cadherin in TERT-siSFRP1 cells is likely due to the misregulation of a combination of E-cadherin transcriptional factors including ZEB1, Twist, Snail, and Slug. The expression of vimentin may be mediated by $\beta$-catenin in TERT- 
siSFRP1 cells since $\beta$-catenin can transactivate vimentin in breast cancer cells [46] and $\beta$-catenin activity is enhanced in TERT-siFRP1 cells [16]. Taken together, this research suggests that a reduction of SFRP1 can sensitize immortalized mammary epithelial cells to enhanced migration through an increased activation and sensitivity of the TGF- $\beta$ signaling pathway.

\section{Conclusions}

This is the first report to suggest that the loss of a Wnt signaling antagonist, SFRP1, plays a direct role in TGF$\beta$-mediated signaling and TGF- $\beta$-mediated-cellular migration. Given our results, the crosstalk that occurs between the Wnt/ $\beta$-catenin and TGF $\beta$ signaling pathways seems to be in part synchronized by SFRP1. Experiments to elucidate whether TERT-siSFRP1 cells are tumorigenic in vivo and how TGF- $\beta$ targets are affected by the paracrine signals elicited are ongoing. In addition, this work described here is the first to demonstrate TGF- $\beta$ sensitivity can be partially ameliorated by blocking the expression of ZEB2, a key transcription factor that regulates the progression of tumor cell metastasis. Hence, ZEB2 may be an excellent anti-cancer therapeutic target.

\section{Additional material}

Additional File 1: Genes associated with the TGF- $\beta$ signaling pathway are up-regulated in response to SFRP1 down-regulation. Total RNA was isolated from three separate harvests for real-time PCR analysis of genes involved in the TGF- $\beta$ signaling pathway. All real-time PCR results are from two separate experiments performed in triplicate and results were normalized to amplification of $\beta$-actin mRNA. Bars represent mean \pm SEM and are expressed a fold change with respect to TERT-pSUPER cells. ${ }^{* *} \mathrm{p}<0.01,{ }^{* * *} \mathrm{p}<0.001$ (significantly different from corresponding TERT-pSUPER cell line using students's $t$-test).

\section{Abbreviations}

EMT: epithelial-mesenchymal transition; TGF- $\beta$ : transforming growth factor- $\beta$; LDL: low-density lipoprotein; Dsh: Dishevelled; APC: Adenomatous polyposis coli; GSK3: Glycogen synthase kinase 3; HMG: high mobility group; SFRP1: Secreted frizzled-related protein-1; SIP1: smad interacting protein 1; ZEB2: Zinc finger E-box-binding homeobox 2; PAI-1: plasminogin activator inhibitor type-1; plasminogin activator inhibitor type-1; ERK1/2: extracellular-signalregulated kinase1/2.
\end{abstract}

\section{Acknowledgements}

This work was funded by the Rays of Hope Foundation.

\section{Author details}

${ }^{1}$ Pioneer Valley Life Sciences Institute, Baystate Medical Center, Springfield, MA 01199, USA. ${ }^{2}$ Department of Biochemistry and Molecular Biology, University of Massachusetts, Amherst, MA 01003, USA. ${ }^{3}$ Department of Biology, University of Massachusetts, Amherst, MA 01003, USA. ${ }^{4}$ Department of Veterinary and Animal Sciences, University of Massachusetts, Amherst, MA 01003, USA.

\section{Authors' contributions}

KG drafted the manuscript and performed all of the described experiments. KC treated cells and harvested RNA and protein utilized for the described experiments. MM imaged the migration assay slides, counted cells, and quantified the results. SS participated in the study design, edited the manuscript, and gave final approval of the version to be published. All authors read and approved the final manuscript.

\section{Competing interests}

The authors do not have any financial or personal relationships with other people or organizations that could inappropriately influence the work described in this manuscript.

Received: 16 November 2010 Accepted: 8 February 2011

Published: 8 February 2011

\section{References}

1. Hanahan D, Weinberg RA: The hallmarks of cancer. Cell 2000, 100:57-70.

2. Roberts $A B$, Wakefield LM: The two faces of transforming growth factor beta in carcinogenesis. Proceedings of the National Academy of Sciences of the United States of America 2003, 100:8621-8623.

3. Reynisdottir I, Polyak K, lavarone A, Massague J: Kip/Cip and Ink4 Cdk inhibitors cooperate to induce cell cycle arrest in response to TGF-beta. Genes \& development 1995, 9:1831-1845.

4. Savagner P: Leaving the neighborhood: molecular mechanisms involved during epithelial-mesenchymal transition. Bioessays 2001, 23:912-923.

5. Muraoka RS, Dumont N, Ritter CA, Dugger TC, Brantley DM, Chen J, Easterly E, Roebuck LR, Ryan S, Gotwals PJ, et al: Blockade of TGF-beta inhibits mammary tumor cell viability, migration, and metastases. The Journal of clinical investigation 2002, 109:1551-1559.

6. Muraoka-Cook RS, Shin I, Yi JY, Easterly E, Barcellos-Hoff MH, Yingling JM, Zent R, Arteaga CL: Activated type I TGFbeta receptor kinase enhances the survival of mammary epithelial cells and accelerates tumor progression. Oncogene 2006, 25:3408-3423.

7. Siegel PM, Shu W, Cardiff RD, Muller WJ, Massague J: Transforming growth factor beta signaling impairs Neu-induced mammary tumorigenesis while promoting pulmonary metastasis. Proceedings of the National Academy of Sciences of the United States of America 2003, 100:8430-8435.

8. Polakis P: Wnt signaling and cancer. Genes \& development 2000, 14:1837-1851.

9. Brown AM: Wnt signaling in breast cancer: have we come full circle? Breast Cancer Res 2001, 3:351-355.

10. Brennan KR, Brown AM: Wnt proteins in mammary development and cancer. Journal of mammary gland biology and neoplasia 2004, 9:119-131.

11. Finch PW, He X, Kelley MJ, Uren A, Schaudies RP, Popescu NC, Rudikoff S, Aaronson SA, Varmus HE, Rubin JS: Purification and molecular cloning of a secreted, Frizzled-related antagonist of Wnt action. Proceedings of the National Academy of Sciences of the United States of America 1997, 94:6770-6775.

12. Bafico A, Gazit A, Pramila T, Finch PW, Yaniv A, Aaronson SA: Interaction of frizzled related protein (FRP) with Wnt ligands and the frizzled receptor suggests alternative mechanisms for FRP inhibition of Wnt signaling. The Journal of biological chemistry 1999, 274:16180-16187.

13. Zhou Z, Wang J, Han X, Zhou J, Linder S: Up-regulation of human secreted frizzled homolog in apoptosis and its down-regulation in breast tumors. International journal of cancer 1998, 78:95-99.

14. Wong SC, Lo SF, Lee KC, Yam JW, Chan JK, Wendy Hsiao WL: Expression of frizzled-related protein and Wnt-signalling molecules in invasive human breast tumours. J Pathol 2002, 196:145-153.

15. Klopocki E, Kristiansen G, Wild PJ, Klaman I, Castanos-Velez E, Singer G, Stohr R, Simon R, Sauter G, Leibiger H, et al: Loss of SFRP1 is associated with breast cancer progression and poor prognosis in early stage tumors. International journal of oncology 2004, 25:641-649.

16. Gauger KJ, Hugh JM, Troester MA, Schneider SS: Down-regulation of sfrp1 in a mammary epithelial cell line promotes the development of a cd44high/cd24low population which is invasive and resistant to anoikis. Cancer cell international 2009, 9:11.

17. Verschueren K, Remacle JE, Collart C, Kraft H, Baker BS, Tylzanowski P, Nelles L, Wuytens G, Su MT, Bodmer R, et al: SIP1, a novel zinc finger/ homeodomain repressor, interacts with Smad proteins and binds to $5^{\prime}$ CACCT sequences in candidate target genes. The Journal of biological chemistry 1999, 274:20489-20498.

18. Vandewalle C, Comijn J, De Craene B, Vermassen P, Bruyneel E, Andersen H, Tulchinsky E, Van Roy F, Berx G: SIP1/ZEB2 induces EMT by repressing 
genes of different epithelial cell-cell junctions. Nucleic acids research 2005, 33:6566-6578.

19. Chomczynski P, Sacchi N: Single-step method of RNA isolation by acid guanidinium thiocyanate-phenol-chloroform extraction. Anal Biochem 1987, 162:156-159

20. Micalizzi DS, Christensen KL, Jedlicka P, Coletta RD, Baron AE, Harrell JC, Horwitz KB, Billheimer D, Heichman KA, Welm AL, et al: The Six1 homeoprotein induces human mammary carcinoma cells to undergo epithelial-mesenchymal transition and metastasis in mice through increasing TGF-beta signaling. The Journal of clinical investigation 2009, 119:2678-2690.

21. Miyazono K: Transforming growth factor-beta signaling in epithelialmesenchymal transition and progression of cancer. Proceedings of the Japan Academy 2009, 85:314-323.

22. Sandler MA, Zhang JN, Westerhausen DR Jr, Billadello JJ: A novel protein interacts with the major transforming growth factor-beta responsive element in the plasminogen activator inhibitor type-1 gene. The Journal of biological chemistry 1994, 269:21500-21504.

23. Ignotz RA, Heino J, Massague J: Regulation of cell adhesion receptors by transforming growth factor-beta. Regulation of vitronectin receptor and LFA-1. The Journal of biological chemistry 1989, 264:389-392.

24. Giehl K, Imamichi Y, Menke A: Smad4-independent TGF-beta signaling in tumor cell migration. Cells, tissues, organs 2007, 185:123-130.

25. Attisano L, Labbe E: TGFbeta and Wnt pathway cross-talk. Cancer metastasis reviews 2004, 23:53-61.

26. Guo X, Wang XF: Signaling cross-talk between TGF-beta/BMP and other pathways. Cell research 2009, 19:71-88.

27. Labbe E, Lock L, Letamendia A, Gorska AE, Gryfe R, Gallinger S, Moses HL, Attisano $\mathrm{L}$ : Transcriptional cooperation between the transforming growth factor-beta and Wnt pathways in mammary and intestinal tumorigenesis. Cancer research 2007, 67:75-84.

28. Hussein SM, Duff EK, Sirard C: Smad4 and beta-catenin co-activators functionally interact with lymphoid-enhancing factor to regulate graded expression of Msx2. The Journal of biological chemistry 2003, 278:48805-48814.

29. James D, Levine AJ, Besser D, Hemmati-Brivanlou A: TGFbeta/activin/nodal signaling is necessary for the maintenance of pluripotency in human embryonic stem cells. Development (Cambridge, England) 2005, 132:1273-1282.

30. Gauger K, Rodriguez-Cortes A, Hartwich M, Schneider SS: Rhodiola Crenulata inhibits the tumorigenic properties of invasive mammary epithelial cells with stem cell characteristics. Journal of Medicinal Plants Research 2010, 5.

31. Shipitsin M, Campbell LL, Argani P, Weremowicz S, Bloushtain-Qimron N, Yao J, Nikolskaya T, Serebryiskaya T, Beroukhim R, Hu M, et al: Molecular definition of breast tumor heterogeneity. Cancer cell 2007, 11:259-273.

32. Baum O, Hlushchuk R, Forster A, Greiner R, Clezardin P, Zhao Y, Djonov V, Gruber G: Increased invasive potential and up-regulation of MMP-2 in MDA-MB-231 breast cancer cells expressing the beta3 integrin subunit. International journal of oncology 2007, 30:325-332.

33. Galliher AJ, Schiemann WP: Src phosphorylates Tyr284 in TGF-beta type II receptor and regulates TGF-beta stimulation of p38 MAPK during breast cancer cell proliferation and invasion. Cancer research 2007, 67:3752-3758.

34. Sheldrake HM, Patterson LH: Function and antagonism of beta3 integrins in the development of cancer therapy. Current cancer drug targets 2009, 9:519-540.

35. Ulisse S, Baldini E, Sorrenti S, D'Armiento M: The urokinase plasminogen activator system: a target for anti-cancer therapy. Current cancer drug targets 2009, 9:32-71.

36. Dass K, Ahmad A, Azmi AS, Sarkar SH, Sarkar FH: Evolving role of uPA/ uPAR system in human cancers. Cancer treatment reviews 2008, 34:122-136.

37. Bajou K, Noel A, Gerard RD, Masson V, Brunner N, Holst-Hansen C, Skobe M, Fusenig NE, Carmeliet P, Collen D, Foidart JM: Absence of host plasminogen activator inhibitor 1 prevents cancer invasion and vascularization. Nature medicine 1998, 4:923-928.

38. Gutierrez LS, Schulman A, Brito-Robinson T, Noria F, Ploplis VA, Castellino FJ: Tumor development is retarded in mice lacking the gene for urokinasetype plasminogen activator or its inhibitor, plasminogen activator inhibitor-1. Cancer research 2000, 60:5839-5847.
39. Leik CE, Su EJ, Nambi P, Crandall DL, Lawrence DA: Effect of pharmacologic plasminogen activator inhibitor-1 inhibition on cell motility and tumor angiogenesis. J Thromb Haemost 2006, 4:2710-2715.

40. Maillard C, Jost M, Romer MU, Brunner N, Houard X, Lejeune A, Munaut C, Bajou K, Melen L, Dano K, et al: Host plasminogen activator inhibitor1 promotes human skin carcinoma progression in a stage-dependent manner. Neoplasia (New York, NY 2005, 7:57-66.

41. Elloul S, Elstrand MB, Nesland JM, Trope CG, Kvalheim G, Goldberg I, Reich R, Davidson B: Snail, Slug, and Smad-interacting protein 1 as novel parameters of disease aggressiveness in metastatic ovarian and breast carcinoma. Cancer 2005, 103:1631-1643.

42. Imamichi Y, Waidmann O, Hein R, Eleftheriou P, Giehl K, Menke A: TGF beta-induced focal complex formation in epithelial cells is mediated by activated ERK and JNK MAP kinases and is independent of Smad4. Biol Chem 2005, 386:225-236.

43. Mikkers H, Allen J, Knipscheer P, Romeijn L, Hart A, Vink E, Berns A: Highthroughput retroviral tagging to identify components of specific signaling pathways in cancer. Nat Genet 2002, 32:153-159.

44. Comijn J, Berx G, Vermassen P, Verschueren K, van Grunsven L, Bruyneel E, Mareel M, Huylebroeck D, van Roy F: The two-handed E box binding zinc finger protein SIP1 downregulates E-cadherin and induces invasion. Molecular cell 2001, 7:1267-1278

45. Bindels $S$, Mestdagt $M$, Vandewalle $C$, Jacobs $N$, Volders $L$, Noel $A$, van Roy F, Berx G, Foidart JM, Gilles C: Regulation of vimentin by SIP1 in human epithelial breast tumor cells. Oncogene 2006, 25:4975-4985.

46. Gilles $C$, Polette $M$, Mestdagt $M$, Nawrocki-Raby B, Ruggeri P, Birembaut $P$, Foidart JM: Transactivation of vimentin by beta-catenin in human breast cancer cells. Cancer research 2003, 63:2658-2664.

\section{Pre-publication history}

The pre-publication history for this paper can be accessed here: http://www.biomedcentral.com/1471-2407/11/59/prepub

\section{doi:10.1186/1471-2407-11-59}

Cite this article as: Gauger et al: SFRP1 reduction results in an increased sensitivity to TGF- $\beta$ signaling. BMC Cancer 2011 11:59.

\section{Submit your next manuscript to BioMed Central and take full advantage of:}

- Convenient online submission

- Thorough peer review

- No space constraints or color figure charges

- Immediate publication on acceptance

- Inclusion in PubMed, CAS, Scopus and Google Scholar

- Research which is freely available for redistribution

Submit your manuscript at www.biomedcentral.com/submit
Ciomed Central 